\title{
Capreomycin-induced serum electrolyte abnormalities
}

\author{
A. M. HOLMES, C. M. HESLING, and T. M. WI LS ON \\ Division of Metabolism, Manchester Royal Infirmary, and Baguley Hospital, Manchester
}

Gross electrolyte disturbances including hypokalaemia, hypomagnesaemia, hypocalcaemia, and alkalosis have developed in tuberculous patients who were being treated with capreomycin. Similar abnormalities have also occurred when the drug gentamicin was used and were found to be due to secondary hyperaldosteronism. In this paper a detailed description of the changes induced by capreomycin is given. The evidence available strongly suggests a similar aetiology for the biochemical changes, but the precise pathophysiology is unknown. Caution should be exercised when capreomycin is used and the drug should be withdrawn if any of these abnormalities develop.

Hypokalaemia, hypomagnesaemia, and alkalosis, which developed in patients treated with gentamicin for pulmonary tuberculosis, were shown to be due to a drug-induced secondary hyperaldo. steronism (Holmes, Hesling, and Wilson, 1970). Similar biochemical abnormalities have developed in 3 out of 67 tuberculous patients who were being given capreomycin (Table I) (Wilson, 1967 ;

T A B L E I

BIOCHEMICAL DATA DURING ELECTROLYTE DISTUR-

\begin{tabular}{|c|c|c|c|c|c|}
\hline & & \multicolumn{3}{|c|}{ Patient No. } & \multirow{2}{*}{ Controls } \\
\hline & & 1 & 2 & 3 & \\
\hline \multirow{3}{*}{$\begin{array}{l}\text { Serum potassium } \\
\text { (mEq q/l.) } \\
\text { Serum sodium } \\
\text { (mEq/l.) } \\
\text { Serum chloride } \\
\text { (mEq/l.). }\end{array}$} & . . & $2 \cdot 0$ & $3 \cdot 2$ & 1.9 & $4.7: 0.3$ \\
\hline & .. & 130 & 128 & 125 & $140 \pm 2 \cdot 2$ \\
\hline & .. & 70 & 86 & 69 & $97 \succeq 2 \cdot 7$ \\
\hline $\begin{array}{l}\text { Serum calcium } \\
\text { (mg./100 ml.) } \\
\text { Serum magnesium }\end{array}$ & . & $6 \cdot 4$ & $8 \cdot 8$ & $8 \cdot 0$ & $9 \cdot 9 \pm 0 \cdot 7$ \\
\hline $\begin{array}{l}\text { Serum magnesium } \\
\text { (mg./100 ml.) }\end{array}$ & .. & $\overline{38}$ & $\overline{20}$ & 0.9 & $2 \cdot 0 \pm 0 \cdot 2$ \\
\hline $\begin{array}{c}\text { Total venous } \mathrm{CO}_{2} \\
\text { (mEq/1.) } \\
\text { Blood urea }\end{array}$ & : & 38 & 29 & & \\
\hline $\begin{array}{l}\text { Blood urea } \\
\text { (mg./100 ml.) }\end{array}$ & .. & 43 & 42 & 29 & $27 \pm 5$ \\
\hline $\begin{array}{l}\text { Serum albumin } \\
(\mathrm{g} . / 100 \mathrm{ml} .)\end{array}$ & .. & $3 \cdot 1$ & - & $3 \cdot 2$ & $4.2 \pm 0.6$ \\
\hline
\end{tabular}

The duration of disease in the control patients varied from a few weeks to many years. The disease was confined to the lungs, none had anorexia, diarrhoea or had been treated with diuretics, gentamicin, viomycin or capreomycin.

Hesling, 1969 ; Citron, 1969) The evidence so far available suggests that drug-induced secondary hyperaldosteronism may also be responsible for these changes. This paper gives details of three patients in whom abnormalities developed during the course of therapy with capreomycin.

\section{METHODS}

The patient. admitted to the Metabolic Ward, received a self-selected constant diet which approximated closely to her previous food intake. Conventional metabolic techniques established in the laboratory were used (Stanbury and Lumb, 1962). Urine was collected under oil in 24-hour aliquots and faeces were collected in four-day periods. Electrolytes were measured by conventional techniques, nitrogen by the micro-Kjeldahl method and the serum calcium and magnesium in patient 3 by atomic absorption flame spectrophotometry. The plasma renin was estimated using an enzyme kinetic technique (Brown, Davies, Lever, Robertson, and Tree, 1964) (normal range 4-20 units per litre). Plasma hydroxycorticosteroids were estimated using the Mattingly (1962) method.

CASE 1 A girl aged 19 developed pulmonary tuberculosis in 1951. Subsequent treatment with streptomycin, thiosemicarbazone, para-amino salicylic acid, isoniazid, viomycin, cycloserine, pyrazinamide, pneumoperitoneum, and bilateral upper lobectomies had failed to cure the disease. On 2 September 1964 therapy with capreomycin, $1 \mathrm{~g}$., ethambutol, $1,250 \mathrm{mg}$., and isoniazid, $400 \mathrm{mg}$. daily, was started (Table II). She remained well until 14 July 1966, when she developed visual hallucinations and tetany. The serum

\section{T A B L E I I}

DRUG THERAPY DURING WHICH THE DEVELOPMENT OF BIOCHEMICAL ABNORMALITIES OCCURRED

\begin{tabular}{|c|c|c|c|c|}
\hline \multirow{2}{*}{\multicolumn{2}{|c|}{ Drugs and Daily Dose }} & \multicolumn{3}{|c|}{ Patient No. } \\
\hline & & 1 & 2 & 3 \\
\hline $\begin{array}{l}\text { Capreomycin (g.) } \\
\text { Ethambutol (mg.) } \\
\text { Isoniazid (mg.). } \\
\text { Duration of therapy (mth) }\end{array}$ & $\begin{array}{l}\cdots \\
\cdots \\
\cdots\end{array}$ & $\begin{array}{r}1 \\
1,250 \\
400 \\
22\end{array}$ & $\begin{array}{r}1 \\
800 \\
300 \\
6\end{array}$ & $\begin{array}{r}1 \\
800 \\
300 \\
26\end{array}$ \\
\hline
\end{tabular}


calcium was $6.4 \mathrm{mg} . / 100 \mathrm{ml}$; serum sodium 130 $\mathrm{mEq} /$ litre; serum potassium $2.0 \mathrm{mEq} /$ litre; serum chloride $70 \mathrm{mEq} /$ litre, and total venous $\mathrm{CO}_{2} 38 \mathrm{mEq} /$ litre. The blood urea was $43 \mathrm{mg} . / 100 \mathrm{ml}$. and serum albumin $3 \cdot 1 \mathrm{~g} / 100 \mathrm{ml}$. (Table I). There was no proteinuria.

Antituberculosis therapy was stopped, she was given calcium and potassium supplements and the serum electrolytes returned to normal within three weeks. No alternative drug therapy was available and the patient died from respiratory failure on 22 February 1967. A necropsy was performed but no renal or adrenal lesion was found.

CASE 2 A 65-year-old man developed pulmonary tuberculosis in 1958. In 1966 the bacterial strain was found to be resistant in vitro to the standard antituberculosis drugs and on 7 September 1966 treatment with capreomycin, 1 g., ethambutol, $800 \mathrm{mg}$., and isoniazid, $300 \mathrm{mg}$. daily, was started (Table II). The serum electrolytes and blood urea were within normal limits. On 25 March 1967 he complained of general malaise and four days later the serum calcium was $7.7 \mathrm{mg} . / 100 \mathrm{ml}$, serum sodium $134 \mathrm{mEq} /$ litre, serum potassium $3.5 \mathrm{mEq} /$ litre, serum chloride 86 $\mathrm{mEq} /$ litre, and total venous $\mathrm{CO}_{2} 33 \mathrm{mEq} /$ litre. The blood urea was $42 \mathrm{mg} . / 100 \mathrm{ml}$. By 3 April 1967 the serum sodium had fallen to $128 \mathrm{mEq} /$ litre, serum potassium $3.2 \mathrm{mEq} /$ litre, serum chloride $86 \mathrm{mEq} /$ litre, serum calcium $8.8 \mathrm{mg} . / 100 \mathrm{ml}$., and blood urea $42 \mathrm{mg}$. $/ 100 \mathrm{ml}$. (Table I). There was no proteinuria. Antituberculosis therapy was stopped, supplementary potassium and calcium were given and within four weeks the serum electrolytes were normal.

CASE 3 A 27-year-old Pakistani woman developed tuberculosis in 1958. Previous therapy in Pakistan had included streptomycin, para-aminosalicylic acid, isoniazid, cycloserine, ethionamide, pneumoperitoneum, and a left-sided wax plombage. She emigrated to England in 1967 and in November of that year treatment with capreomycin, 1 g., ethambutol. 800 mg., and isoniazid, $300 \mathrm{mg}$. daily, was started (Table II). On 21 January 1969 the serum sodium was 139 $\mathrm{mEq} /$ litre, serum potassium $3.4 \mathrm{mEq} /$ litre, serum chloride $93 \mathrm{mEq} /$ litre, serum $\mathrm{CO}_{2} 28 \mathrm{mEq} /$ litre, and blood urea $20 \mathrm{mg}$. $/ 100 \mathrm{ml}$. The uncorrected creatinine clearance was $67 \mathrm{ml}$. per minute. Therapy was stopped on 24 January when a left thoracoplasty was performed and the wax plombage was removed. The changes in serum electrolytes in the post-operative period are illustrated (Fig. 1). During the first six post-operative days her oral daily fluid intake had been about $500 \mathrm{ml}$. of milk and fruit juice and an intravenous infusion of $5 \%$ dextrose in $1 / 5$ normal saline had contributed a daily sodium intake of $\mathbf{3 0}$ mEq.

On the sixth post-operative day (30 January 1969) she developed tetany. Clinical examination revealed normal skin turgor and venous filling. The pulse was $140 /$ minute, blood pressure $100 / 70 \mathrm{~mm}$. $\mathrm{Hg}$, and

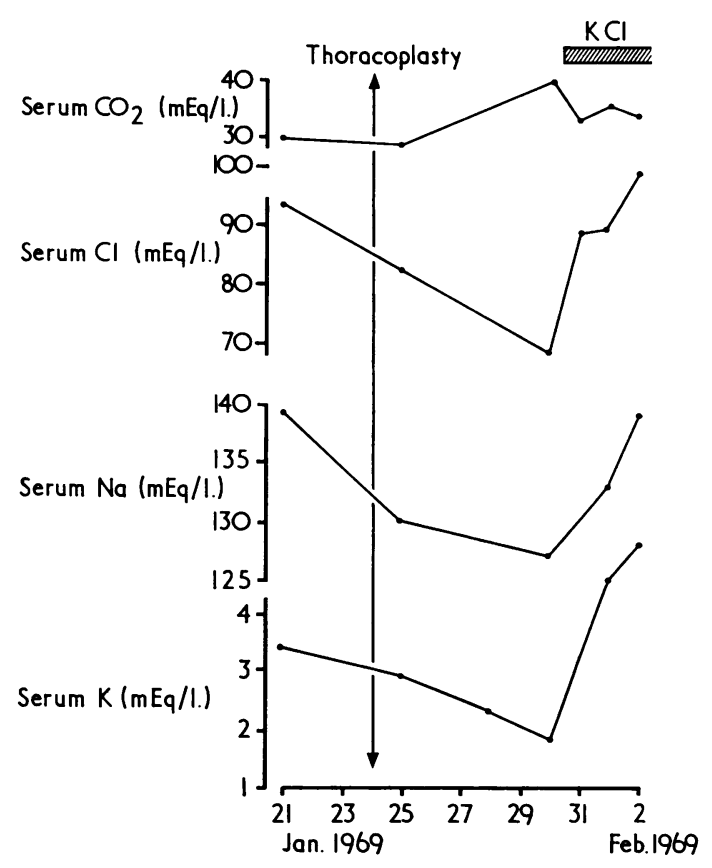

FIG. 1. Case 3. Changes in serum electrolytes in the immediate post-operative period.

there was no postural hypotension. Air entry on the left side of the chest was poor. The reflexes were brisk and the plantar responses flexor. Trousseau's sign was positive. The serum potassium was $1.9 \mathrm{mEq} /$ litre ; serum chloride $69 \mathrm{mEq} /$ litre ; the other results can be seen in Table I. The plasma 17-hydroxycorticosteroids were normal. The urinary electrolytes are given as $\mathrm{mEq} /$ litre because a full 24 hours urine could not be collected before therapy with potassium chloride was begun. The urinary sodium was $13 \mathrm{mEq} /$ litre; potassium $109 \mathrm{mEq} /$ litre ; chloride $46 \mathrm{mEq} /$ litre; magnesium $9.1 \mathrm{mg}$./litre, and calcium $28 \mathrm{mg}$./ litre. Measurements of the osmolality of specimens of serum and urine which were obtained simultaneously were 247 and $399 \mathrm{~m}$.osmols/litre respectively. There was no proteinuria, no aminoaciduria, and the creatinine clearance was $50 \mathrm{ml}$./minute.

It was thought that patient 3 was depleted of both potassium and magnesium, but it was more difficult to account for the hyponatraemia and disparate serum and urine osmolalities. Because of the possibility of an inappropriate secretion of antidiuretic hormone, vide infra, her fluid intake was restricted to $500 \mathrm{ml}$. daily for the next three days and she was transferred to the Manchester Royal Infirmary for further investigation.

She was a small woman (weight $44 \mathrm{~kg}$.), and was given a self-selected constant diet which contained by analysis $72 \mathrm{mEq}$ sodium, $72 \mathrm{mEq}$ chloride, $62 \mathrm{mEq}$ 
potassium, $10.4 \mathrm{~g}$. nitrogen, $178 \mathrm{mg}$. magnesium, 374 mg. calcium, and $900 \mathrm{mg}$. phosphorus per day. A supplement of $240 \mathrm{mEq}$ of potassium as the chloride was given daily. By 2 February the serum potassium had risen to $5.5 \mathrm{mEq} /$ litre (Fig. 2) and the supplement was stopped. Three days later the serum potassium had fallen to $2.9 \mathrm{mEq} /$ litre and a further daily supplement of $167 \mathrm{mEq}$ was given until 18 February. Between 6 and 18 February a total of $470 \mathrm{mEq}$ of potassium had been retained and the serum potassium had risen to $4.6 \mathrm{mEq} /$ litre. The potassium supplement was again stopped and the serum potassium values subsequently remained normal.

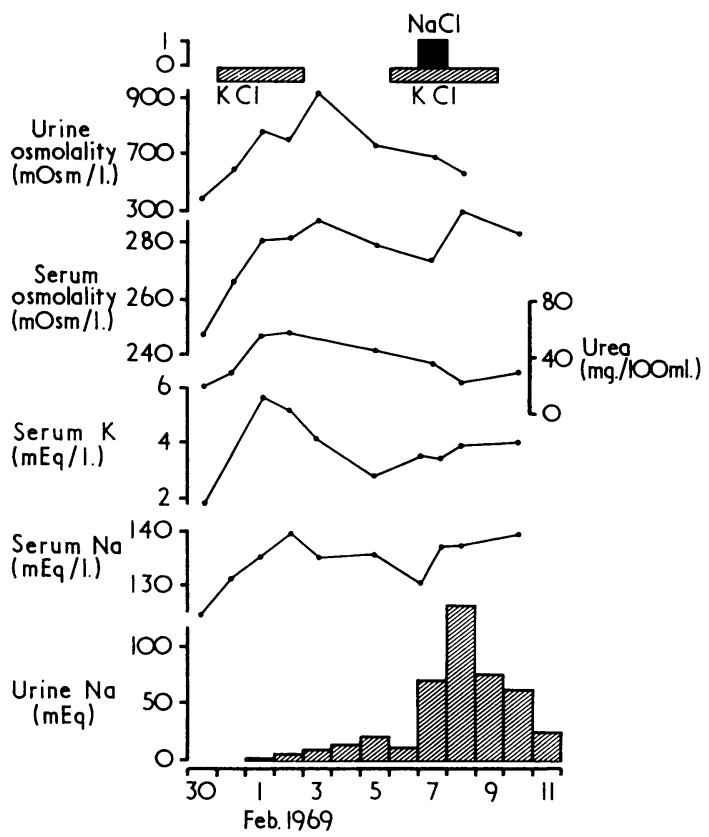

FIG. 2. Case 3. Pattern of recovery.

During the period of quantitative metabolic study $780 \mathrm{mg}$. of magnesium was retained and the serum magnesium rose from $0.9 \mathrm{mg} . / 100 \mathrm{ml}$. to $1.7 \mathrm{mg} . /$ $100 \mathrm{ml}$. The serum calcium rose concurrently from 8.0 to $9.4 \mathrm{mg}$. $/ 100 \mathrm{ml}$. despite the patient being $2.5 \mathrm{~g}$. in negative calcium balance.

The patient on admission showed no clinical signs of sodium deficiency, but the serum sodium was 125 $\mathrm{mEq} /$ litre. Restriction of oral fluids to $500 \mathrm{ml}$. daily caused a rise in the serum sodium to $140 \mathrm{mEq} /$ litre, but when tested on 18 February she was able to excrete a 2-litre water load normally.

The hyponatraemia was associated with a low urinary sodium (13 mEq/litre) and with a rise in plasma renin (60 units/litre on 30 January 1969), though the expected plasma renin level for the sixth post- operative day is not known. When she was given an intravenous infusion of $300 \mathrm{mEq}$ sodium chloride most of this was excreted in the urine (Fig. 2), but a cumulative retention of $560 \mathrm{mEq}$ was recorded over the 30-day period of balance. The plasma renin had fallen to 14 units/litre by. 18 February. There had been no change in body weight or blood pressure.

\section{DISCUSSION}

The principal biochemical features of the syndrome which developed in these three patients were hypokalaemia, hypomagnesaemia, hypocalcaemia, and a hypochloraemic extracellular alkalosis. All three had been taking a combination of capreomycin, ethambutol, and isoniazid for 22 , 6, and 26 months respectively. Ethambutol and isoniazid have been used widely for the treatment of pulmonary tuberculosis and side-effects similar to those described have not been reported. Capreomycin is known to produce renal tubular damage when given in large doses to laboratory animals (Welles, Harris, Small, Worth, and Anderson, 1966). Yue and Cohen (1966) reported the development of acute tubular necrosis in a woman who had had four weeks' treatment with capreomycin, and Miller, Popplewell, Landwehr, and Greene (1966) found some elevation of the blood urea nitrogen in 8 of 300 patients given the drug.

The biochemical changes occurring in these patients are strikingly similar to those previously reported in patients treated with gentamicin (Holmes et al., 1970) and with viomycin (Werner, Tompsett, Muschenheim, and McDermott, 1951). In the patients treated with gentamicin the syndrome was considered to be due to a drug-induced secondary hyperaldosteronism causing urinary loss of potassium and magnesium.

Magnesium deficiency impairs the capacity of parathyroid hormone to raise the serum calcium (Estep, Shaw, Watlington, Hobe, Holland, and Tucker, 1968; Shils, 1969). The low serum calcium levels found in these patients may have reflected a failure of response of the bones to parathyroid hormone as a result of depletion of magnesium.

We have no definitive measurements of the plasma aldosterone levels in our patients, but an elevated plasma renin of 60 units/litre was found in patient 3 at a time when the biochemical features of hyperaldosteronism were seen. We think it unlikely that this considerable elevation in plasma renin could be explained by the surgery alone. It seems likely that these patients had also developed a state of secondary aldosteronism. 
In patient 3 the initially low serum sodium values could have been due either to an inappropriate secretion of antidiuretic hormone or to sodium depletion. Inappropriate secretion of antidiuretic hormone has been found both postoperatively (Moran, Miltenberger, Shuayb, and Zimmermann, 1964 ; Deutsch, Goldberg, and Dripps, 1966) and in patients with pulmonary tuberculosis (Weiss and Katz, 1965). This is, however, associated with a low aldosterone secretion rate (Turin, Cooke, and Walker, 1968), whereas the plasma renin was elevated in patient 3 , and when tested she was able to excrete a water load normally.

The low urinary sodium, high plasma renin, and retention of $560 \mathrm{mEq}$ sodium during the balance period would point towards the secondary hyperaldosteronism being the result of sodium depletion, but with the evidence available it is not possible for us to be dogmatic about the precise way in which the condition is produced. We have given much thought to the possible role of renal tubular damage - there was no proteinuria, phosphaturia, glycosuria or abnormal aminoaciduriaand have found no evidence to suggest a primary tubular effect. This is not to say that capreomycin might not have a direct toxic effect on the renal tubules, but merely that we have no evidence to support this. The drug could directly stimulate the juxtaglomerular cells, but we are unaware of this having occurred in other situations.

When prolonged capreomycin therapy is necessary for the treatment of patients with pulmonary tuberculosis we would recommend that monthly estimations of the serum electrolytes are made and that the drug is stopped should hypokalaemia or hypomagnesaemia develop.

\section{REFERENCES}

Brown, J. J., Davies, D. L., Lever, A. F., Robertson, J. I. S., and Tree, M. (1964). The estimation of renin in human plasma. Biochem. J., 93, 594.

Citron, K. (1969). Personal communication.

Deutsch, S., Goldberg, M., and Dripps, R. D. (1966). Postoperative hyponatremia with the inappropriate release of antidiuretic hormone. Anesthesiology, 27, 250.

Estep, H., Shaw, W., Watlington, C. O., Hobe, C., Holland, W., and Tucker, H. (1968). Hypocalcemia due to reversible PTH resistance. Clin. Res., 16, 265.

Hesling, C. M. (1969). Treatment with capreomycin, with special reference to toxic effects. Tubercle (Lond.), 50, Suppl. p. 39.

Holmes, A. M., Hesling, C. M., and Wilson, T. M. (1970). Drug induced secondary aldosteronism in patients with pulmonary tuberculosis. Quart. J. Med., in press.

Mattingly, D. (1962). A simple fluorimetric method for the estimation of free 11-hydroxycorticoids in human plasma. J. clin. Path., 15, 374.

Miller, J. D., Popplewell, A. G., Landwehr, A., and Greene, M. E (1966). Toxicology studies in patients on prolonged therapy with capreomycin. Ann. N.Y. Acad. Sci., 135, 1047.

Moran, W. H., Miltenberger, F. W., Shuayb, W. A., and Zimmermann, B. (1964). The relationship of antidiuretic hormone secretion to surgical stress. Surgery, 56, 99.

Shils, M. E. (1969). Experimental human magnesium depletion. Medicine (Baltimore), 48, 61 .

Stanbury, S. W., and Lumb, G. A. (1962). Metabolic studies of renal osteodystrophy. I. Calcium, phosphorus and nitrogen metabolism in rickets, osteomalacia and hyperparathyroidism complicating chronic uremia and in the osteomalacia of the adult Fanconi syndrome. Medicine (Baltimore), 41, 1.

Turin, M. D., Cooke, C. R., and Walker, W. G. (1968). Aldosterone secretion in inappropriate antidiuretic hormone and in altered osmoregulation. Clin. Res., 16, 66.

Weiss, H., and Katz, S. (1965). Hyponatremia resulting from apparently inappropriate secretion of antidiuretic hormone in patients with pulmonary tuberculosis. Amer. Rev. resp. Dis., 92, 609.

Welles, J. S., Harris, P. N., Small, R. M., Worth, H. M., and Anderson, R. C. (1966). The toxicity of capreomycin in laboratory animals. Ann. N.Y. Acad. Sci., 135, 960.

Werner, C. A., Tompsett, R., Muschenheim, C., and McDermott, W (1951). The toxicity of viomycin in humans. Amer. Rev. Tuberc., 63, 49.

Wilson, T. M. (1967). Capreomycin and ethambutol. Practitioner, $199,817$.

Yue, W. Y., and Cohen, S. S. (1966). Toxic nephritis with acute renal insufficiency caused by administration of capreomycin. Dis. Chest, 49, 549. 